\title{
KEGIATAN EKSTRAKURIKULER PASKIBRA DALAM RANGKA PEMBINAAN KARAKTER SEMANGAT KEBANGSAAN SISWA
}

\author{
Sitti Uswatun Hasanah \\ Program Studi PPKN Fakultas Ilmu Pendidikan dan Pengetahuan Sosial IKIP PGRI Pontianak \\ Jalan Ampera Nomor 88 Pontianak, Telepon (0561) 748219 Fax. (0561) 6589855 - 78116 \\ email: s_uswatunhasanah@ymail.com
}

\begin{abstract}
Abstrak
Kegiatan ekstrakurikuler paskibra memberikan pengaruh terhadap pembentukan karakter dan sikap siswa karena paskibra dapat menanamkan sikap tegas, bertanggungjawab, disiplin, percaya diri, dan memiliki jiwa kepemimpinan, serta di dalam setiap pelaksanaan program kegiatan ekstrakurikuler paskibra dapat menumbuhkan aspek sikap semangat kebangsaan yakni cinta tanah air, rela berkorban, persatuan dan kesatuan, serta jiwa pembaharu atau pantang menyerah. Sehingga siswa dapat mengemban rasa bangga akan cinta tanah air dan semangat kebangsaan yang bertumpu pada nila-nilai pancasila sebagai pedoman hidup bangsa Indonesia. Keberadaan kegiatan ekstrakurikuler paskibra tidak hanya berperan positif dalam membangun sikap disiplin tetapi juga nasionalisme, yang sejalan dengan tujuan pendidikan kewarganegaraan yaitu menumbuhkan wawasan dan kesadaran bernegara serta membentuk sikap dan prilaku cinta tanah air bersendikan kebudayaan bangsa.
\end{abstract}

Kata Kunci: kegiatan ekstrakurikuler, paskibra, karakter, semangat kebangsaan

\begin{abstract}
Paskibra extracurricular activities influence the formation of students' character and attitudes because paskibra can instill a firm, responsible, disciplined, confident attitude, and have a leadership spirit, and in every program implementation of postkibra extracurricular activities can foster aspects of the attitude of the spirit of nationalism that is the love of the motherland, willing to sacrifice, unity and unity, as well as the spirit of reformer or never give up. So students can carry a sense of pride in the love of the motherland and the spirit of nationalism which is based on the values of Pancasila as a guide to the life of the Indonesian people. The existence of postkibra extracurricular activities not only plays a positive role in developing disciplinary attitudes but also nationalism, which is in line with the purpose of citizenship education, which is to foster insight and awareness of the state and to form attitudes and behaviors of patriotism based on national culture.
\end{abstract}

Keywords: extracurricular activities, postkibra, character, national spirit

\section{PENDAHULUAN}

Dunia pendidikan dewasa ini menghadapi berbagai masalah yang kompleks, yang perlu mendapat perhatian. Salah satu masalah tersebut adalah menurunnya rasa kebangsaan. Hal ini terjadi karena faktor-faktor yang mempengaruhinya, yang salah satunya karena adanya globalisasi. Globalisasi adalah suatu proses tatanan masyarakat yang mendunia dan tidak mengenal batas wilayah. Dahlan (dalam Komalasari, 2009: 146-147) mengetengahkan makna globalisasi yang didekati dua pemaknaan, Pertama, globalisasi diartikan sebagai suatu proses meluas atau mendunianya kebudayaan manusia, karena difasilitasi media komunikasi dan informasi yang mendukung kearah perluasan kebudayaan itu. Kedua. globalisasi diartikan proses menyempitnya ruang gerak budaya manusia.

Kehadiran globalisasi tentunya membawa pengaruh bagi kehidupan suatu negara termasuk Indonesia. Tantangan yang dahsyat dari globalisasi antara lain liberalisasi dalam bentuk ekonomi dan pasar bebas yang pada gilirannya makin mengubur batas-batas otoritas ekonomi dan juga politik suatu bangsa. Friedman (Manan dan Lan, 2011: 5) dalam bukunya, The Lexus and the Olive 
There: understanding globalization menyatakan bahwa semua negara di dunia kini harus mengenakan pakaian seragam The Golden Straitjcket. Negara harus menjalankan pasar bebas dengan cara membuka pasarnya untuk dimasuki oleh produk-produk dari mana saja di dunia.

Pengaruh tersebut meliputi dua sisi, yaitu pengaruh positif dan pengaruh negatif. Salah satu pengaruh negatif globalisasi adalah memengaruhi identitas suatu bangsa dengan hadirnya produkproduk luar. Masyarakat Indonesia, khususnya anak muda, banyak yang lupa akan identitas diri sebagai bangsa Indonesia, karena gaya hidupnya cenderung meniru budaya barat yang oleh masyarakat dunia dianggap sebagai kiblat. Salah satu realitanya adalah anak muda lebih tertarik terhadap produk-produk luar negeri. Pengaruh gaya hidup barat tersebut secara perlahan akan mengikis rasa semangat kebangsaan generasi muda. Kondisi seperti ini tentu sangat mengkhawatirkan. Ilahi (2012: 10), mengungkapkan bahwa "Di era globalisasi sekarang kobaran semangat nasionalisme generasi muda mulai luntur. lunturnya semangat nasionalisme generasi muda bisa saja menjadi ancaman (treatment) terhadap terkikisnya nilai-nilai patriotisme yang menjadi landasan kecintaan kita terhadap bumi pertiwi tercinta".

Nasionalisme merupakan rasa kesadaran yang kuat berlandaskan atas kesadaran akan pengorbanan yang pernah diderita bersama dalam sejarah dan atas kemauan menderita hal-hal itu dimasa depan. Sikap kebangsaan tidak tumbuh dengan sendirinya. Upaya menumbuhkan dan meningkatkan sikap semangat kebangsaan dapat dilaksanakan melalui jalur pendidikan. Tilaar (2007: 25) dalam bukunya mengindonesia etnitas dan angsa indonesia mengemukakan bahwa ada beberpa faktor penting dalam menumbuhkan sikap kebangsaan. Faktor-faktor tersebut diantaranya : 1) bahasa, 2) budaya, 3) pendidikan. Pendidikan yang tersentralisasi dalam pengertian tertentu dapat menjadisuatu alat pemersatu yang sangat kuat. sekolah sebagai lembaga pendidikan formal dapat menjadi tempat yang strategis untuk menanamkan nilai-nilai kebangsaan dan rasa nasionalisme kepada generasi muda. selain dalam kegiatan belajar mengajar dikelas, penanaman nilai-nilai kebangsaan dan rasa nasionalisme tersebut dapat dilakukan melalui kegiatan ekstrakurekuler.

Kegiatan ekstrakurikuler merupakan kegiatan yang berada diluar materi wajib sekolah untuk mengembangkan minat-minat baru dan menanamkan tanggung jawab siswa sebagai warga negara melalui pengalaman-pengalaman. Hasilnya setiap warganegara indonesia diharapkan memiliki sikap semangat kebangsaan yang tinggi sehingga memiliki rasa bangga dan cinta terhadap bangsa sendiri. Jika masalah semakin memudarnya semangat kebangsaan generasi muda tidak segera diatasi, negara ini akan hancur. Sebab generasi muda merupakan generasi penerus bangsa yang akan melanjutkan kepemimpinan yang lebih baik di masa depan. Penanaman nilai-nilai semangat kebangsaan pada generasi muda harus ditanamkan sejak dibangku sekolah sebagai lembaga 
pendidikan. Sekolah adalah organisasi layanan yang melakukan kegiatan belajar dan mengajar antara pendidik dan peserta didik. Eksistensi organisasi ekstrakurikuler adalah salah satu nilai strategis untuk meningkatkan semangat kebangsaan. Keberadaan ekstrakurikuler di persekolahan merupakan hal yang penting dalam meningkatkan semangat kebangsaan siswa. Dirjen Dikdasmen dalam SK Nomor 2226/C/Kep/O/1992, menyatakan bahwa:

Kegiatan ekstrakurikuler sebagai kegiatan di luar jam pelajaran biasa dan pada waktu libur sekolah yang dilakukan baik di sekolah maupun di luar sekolah, dengan tujuan untuk memperdalam dan memperluas pengetahuan siswa, mengenal hubungan antara berbagai pelajaran,menyalurkan bakat dan minat serta melengkapi upaya pembinaan manusia seutuhnya.

Eksistensi ekstrakurikuler lebih mengandalkan inisiatif sekolah. Setiap sekolah mempunyai ekstrakurikuler yang berbeda-beda, seperti Marching Band, Pramuka, PMR (Palang Merah Remaja), Paskibra, Teater, dan Pencinta Alam. Arif (2012: 36) mengatakan bahwa secara sederhana istilah kegiatan ekstrakurikuler mengandung pengertian yang menunjukkan segala macam aktivitas di sekolah atau lembaga pendidikan yang dilaksanakan di luar jam pelajaran. Sedangkan Paskibra merupakan kepanjangan dari Pasukan Pengibar Bendera. Jadi, kegiatan ekstrakurikuler Paskibra merupakan suatu kegiatan atau aktivitas di sekolah atau lembaga pendidikan yang dilaksanakan di luar jam pelajaran yang bertugas sebagai pengibar bendera.

Lunturnya nilai-nilai kebangsaan yang sedang diderita anak negeri ini salah satunya yaitu tercermin dari sikap siswa saat mengikuti upacara bendera yang belum sepenuhnya mengerti dan memahami makna dari pelaksanaaan upacara bendera tersebut. Pelaksanaan upacara bendera di sekolah belum memberikan dampak yang nyata bagi pendidikan dan karakter bangsa. Hal ini disebabkan upacara bendera yang sejak puluhan tahun yang lalu dilaksanakan sekarang dianggap hanya menjadi rutinitas dan menjadi budaya belaka. Ini tercermin dari sikap dan perilaku siswa saat melaksanakan upacara bendera. Merasa bosan dan kurang semangat sehingga siswa cenderung untuk berbicara ataupun bercanda dengan temannya, kurang disiplinnya siswa dalam hal waktu dan baris-berbaris, kurang bertanggung jawab dalam hal mengikuti upacara bendera, dan kurang manghargai jasa para pahlawan yang telah gugur demi merebut kemerdekaan Republik Indonesia.

Salah satu materi pembinaan kesiswaan, yang tercantum dalam keputusan Menteri Pendidikan dan Kebudayaan dengan No. 0416/U/1984 yaitu tentang pendidikan pendahuluan bela negara yang diselenggarakan sekolah antara lain dengan pembentukan dengan pembentuksn pasukan pengibaran bendera (paskibra) sekolah. kegiatan tersebut meliputi berbagai jenis kegiatan, di antaranya peratuturan baris berbaris (PBB). tata upacara bendera (TUB), serta latihan kepemimpinan siswa tingkat perintis dan pemula. 
Tujuan yang diharapkan dari pelaksanaan upacara bendera di sekolah menurut Gunawan (2012: 272) yaitu :
a. Membiasakan bersikap tertip dan disiplin,
b. Membiasakan berpenampilan rapi
c. Meningkatkan kemapuan memimpin
d. Membiasakan kesediaan dipimpin
e. Membina kekompakan dan kerjasama
f. Mempertebal semangat kebangsaan

Dari tujuan tersebut tampak bahwa kegiatan ekstrakurikuler paskibra mempunyai peranan yang berkaitan dengan pembinaan dan pengembangan sikap semangat kebangsaan.

\section{METODE PENELITIAN}

Penelitian ini termasuk penelitian deskriptif kualitatif, yaitu jenis penelitian yang tujuannya untuk menggambarkan fenomena yang bersifat alamiah atau rekayasa manusia (Sugiyono, 2010: 6). Penelitian bermaksud untuk melakukan penyelidikan dengan menggambarkan dan memaparkan keadaan suatu situasi sosial. Penelitian dilaksanakan di 11 lokasi SMA Negeri se Kota Pontianak yakni: SMAN 1 kecamatan Pontianak Selatan, SMAN 2 kecamatan Pontianak Barat, SMAN 3 kecamatan Pontianak Selatan, SMAN 4 kecamatan Pontianak Kota, SMAN 5 kecamatan Pontianak Utara, SMAN 6 kecamatan Pontianak Timur, SMAN 7 kecamatan Pontianak Selatan, SMAN 8 kecamatan Pontianak Kota, SMAN 9 kecamatan Pontianak Timur, SMAN 10 kecamatan Pontianak Selatan, dan SMAN 11 kecamatan Pontianak Barat.

\section{PEMBAHASAN}

\section{Kegiatan Ekstrakurikuler Paskibra}

Kegiatan Ekstra Kurikuler adalah kegiatan pendidikan di luar mata pelajaran dan pelayanan konseling untuk membantu pengembangan peserta didik sesuai dengan kebutuhan, potensi, bakat, dan minat mereka melalui kegiatan yang secara khusus diselenggarakan oleh pendidik dan atau tenaga kependidikan yang berkemampuan dan berkewenangan di sekolah/madrasah.

Berbagai referensi mengenai kegiatan ekstrakurikuler diantaranya adalah seperti yang tercantum dalam Surat Keputusan Dikdasmen Nomor 226/C/Kep/O/1992 (Asep Herry H, dkk, 2011:12-4), dalam lampiran tersebut dijelaskan bahwa kegiatan ekstrakurikuler adalah kegiatan di luar jam pelajaran biasa dan pada waktu libur sekolah yang dilaksanakan baik di sekolah ataupun di luar sekolah. Tujuan program kegiatan ekstrakurikuler adalah untuk memperdalam dan memperluas pengetahuan siswa, mengenal hubungan antara berbagai pelajaran, menyalurkan bakat dan minat, serta melengkapi upaya pembinaan manusia seutuhnya. 
Dalam konteks pembinaan manusia seutuhnya, kegiatan ekstrakurikuler memiliki peran yang sangat penting karena pencapaian tujuan tersebut tidak mungkin dapat dicapai hanya mengandalkan kegiatan kurikuler yang waktu dan pelaksanaannya sangat terbatas. Pencapaian tujuan manusia seutuhnya perlu usaha yang terus menerus melalui beberapa program kegiatan ekstrakurikuler yang dapat mendukung program kurikuler. Kegiatan ekstrakurikuler yang diikuti dan dilaksanakan oleh siswa baik di sekolah maupun di luar sekolah, bertujuan agar siswa dapat memperkaya dan memperluas diri. Memperluas diri ini dapat dilakukan dengan memperluas wawasan pengetahuan dan mendorong pembinaan sikap atau nilai-nilai. Segala kegiatan sekolah harus diarahkan pada pembentukan pribadi anak, harus ada kesesuaian antara program dengan kebutuhan masyarakat, harus sesuai dengan karakteristik anak. Salah satu kegiatan yang dapat mendorong pembinaan sikap atau nilai-nilai adalah ekstrakurikuler.

Selanjutnya, dalam Surat Keputusan Mendikbud Nomor 060/U/1993 dan Nomor 080/U/1993 (Asep Herry H, dkk, 2011: 12-4), dijelaskan bahwa, kegiatan ekstrakurikuler adalah kegiatan yang diselenggarakan di luar jam pelajaran yang tercantum dalam susunan program sesuai dengan keadaan dan kebutuhan sekolah. Kegiatan ekstrakurikuler dapat berbentuk kegiatan pengayaan dan kegiatan perbaikan yang berkaitan dengan program kurikuler. Kegiatan ekstrakurikuler diartikan sebagai kegiatan yang diselenggarakan untuk memenuhi tuntutan penguasaan bahan kajian dan pelajaran dengan alokasi waktu yang diatur secara tersendiri berdasarkan pada kebutuhan setiap sekolah. Bentuk kegiatan ekstrakurikuler dapat berupa kegiatan pengayaan dan kegiatan perbaikan yang berkaitan dengan program kurikuler atau kunjungan studi ke tempat-tempat tertentu yang berkaitan dengan esensi materi pelajaran tertentu. Menurut Zainal Aqib \& Sujak (2011: 81) mengatakan bahwa ekstrakurikuler merupakan suatu kegiatan yang diselenggarakan diluar jam pelajaran biasa dalam suatu susunan program pengajaran, disamping untuk lebih mengaitkan antara pengetahuan yang diperoleh dalam program kurikulum demgan keadaan dan kebutuhan lingkungan, juga untuk pengayaan wawasan dan sebagai upaya pemantapan kepribadian. Dalam setiap kegiatan yang dilakukan, pasti tidak lepas dari aspek tujuan. Kerena suatu kegiatan yang diakukan tanpa jelas tujuannya, maka kegiatan itu akan sia-sia. Menurut Asep Herry H, dkk (2011: 12-16) ekstrakurikuler memiliki beberapa tujuan yaitu:

1. Memperluas, memperdalam pengetahuan dan kemampuan atau kompetensi yang relevan dengan program kurikuler. Dalam konteks ini, kegiatan ekstrakurikuler diharapkan dapat memperkaya dan menambah wawasan pengetahuan siswa serta dapat mempertajam kompetensi atau kemampuan siswa sesuai dengan materi yang diajarkan dalam program kurikuler, yang dalam pelaksanaannya memiliki keterbatasan waktu dan program kegiatan

2. Memberikan pemahaman terhadap hubungan antar mata pelajaran. Dalam kegiatan kurikuler, siswa hampir tidak pernah diberikan kesempatan untuk menangkap esensi hubungan antarmata pelajaran. Kajian materi pelajaran sering diberikan secara terpisahpisah. 
Padahal, seluruh materi pelajaran itu diarahkan untuk membentuk kemampuan dan kepribadian yang utuh. Kemampuan dan kepribadian yang utuh itu hanya mungkin diperoleh manakala siswa mampu menangkap hubungan antara berbagai pengetahuan dan pengalaman. Dalam rangka itulah kegiatan ekstrakurikuler diprogramkan.

3. Menyalurkan minat dan bakat siswa. Sekolah sebagai suatu lembaga pendidikan formal tidak hanya berfungsi untuk memberikan pengetahuan dan kemampuan kepada siswa seperti yang diprogramkan dalam kegiatan kurikuler, akan tetapi juga berfungsi untuk mengembangkan kemampuan sesuai minat dan bakat siswa, baik minat dan bakat yang secara langsung berhubungan dengan upaya membekali keterampilan hiup atau pengembangan minat dan bakat yang terbatas hanya sekedar hobi siswa. Semua itu diperlukan untuk mencari keseimbangan pribadi yang utuh.

4. Mendekatkan pengetahuan yang diperoleh dengan kebutuhan dan tuntutan masyarakat atau lingkungan. Sekolah berfungsi untuk mempersiapkan anggota masyarakat agar dapat hidup di masyarakat. Oleh sebab itu, pelajaran yang diberikan di sekolaha harus relevan dengan kebutuhan dan tuntutan masyarakat. Program kegiatan ekstrakurikuler dikembnagkan sebagai jembatan untuk mendekatkan dan mengaitkan antara program kurikuler dengan tuntutan dan kebutuhan masyarakat.

Setiap kegiatan yang diadakan pasti memiliki fungsi. Fungsi dari kegiatan ekstrakurikuler menurut Zainal Aqib \& Sujak (2011: 69), yaitu:

1. Pengembangan, yaitu fungsi kegiatan ekstrakurikuler untuk mengembangkan kemampuan dan kreativitas peserta didik sesuai dengan potensi, bakat dan minat mereka.

2. Sosial, yaitu fungsi kegiatan ekstrakurikuler untuk mengembangkan kemampuan dan rasa tanggung jawab sosial peserta didik

3. Rekreatif, yaitu fungsi kegiatan ekstra kurikuler untuk mengembangkan suasana rileks, mengembirakan dan menyenangkan bagi peserta didik yang menunjang proses perkembangan.

4. Persiapan karir, yaitu fungsi kegiatan ekstra kurikuler untuk mengembangkan kesiapan karir peserta didik.

Paskibra (Pasukan Pengibar Bendera Pusaka) merupakan kegiatan yang bertujuan untuk memupuk semangat kebangsaan, cinta tanah air dan bela negara, kepeloporan dan kepemimpinan, berdisiplin dan berbudi pekerti luhur dalam rangka pembentukan character building generasi muda Indonesia. Peserta kegiatan ini adalah pria dan wanita yang telah terpilih untuk mewakili propinsinya dalam acara pengibaran dan penurunan Bendera Pusaka (duplikat) pada Upacara Kenegaraan 17 Agustus dalam rangka Peringatan Proklamasi Kemerdekaan Republik Indonesia.

Sejarah Paskibraka, dimulai 17 Agustus 1950, saat pertama kali peringatan HUT Proklamasi Kemerdekaan dilaksanakan, setelah Presiden Sukarno hijrah dari Yogyakarta. Namun sebenarnya, dalam peringatan skala kecil pada 1946 silam, kegiatan ini sudah dilaksanakan di Gedung Agung, Yogyakarta. Tata cara penaikan dan penurunan Bendera Pusaka, pertama kali disusun oleh ajudan Presiden Sukarno, Husen Mutahar. Kemudian pada 1967, Husen yang waktu itu menjabat Direktur Jenderal Urusan Pemuda dan Pramuka Dinas Pendidikan dan Kebudayaan di masa pemerintahan Soeharto, juga menerima tugas yang sama. Formasi Paskibraka, diambil dari tanggal, bulan dan tahun dibacakannya Proklamasi kemerdekaan RI. 
Paskibra merupakan pasukan pengibar bendera yang dilaksanakan oleh generasi muda yakni siswa-siswi yang ada di sekolah. Dalam salah satu materi pembinaan kesiswaan, yang tercantum dalam keputusan Menteri Pendidikan dan Kebudayaan dengan No. 0416/U/1984 yaitu tentang Pendidikan Pendahuluan Bela Negara yang diselenggarakan di sekolah. Kegiatan tersebut meliputi berbagai jenis kegiatan, antara lain dengan pembentukan Pasukan Pengibar Bendera (paskibra) sekolah.tersebut meliputi berbagai jenis kegiatan, diantaranya Peraturan Baris Berbaris (PBB), Tata Upacara Bendera (TUB), serta Latihan Kepemimpinan Siswa Tingkat Perintis dan Pemula.

Dari tujuan tersebut, tampak bahwa kegiatan ekstrakulikuler paskibra mempunyai peranan yang berkaitan dengan pembinaan dan pengembangan sikap nasionalisme. Hal ini menunjukkan bahwa ekstrakulikuer paskibra sejalan dengan tujuan Pendidikan Kewarganegaraan yaitu menumbuhkan wawasan dan kesadaran bernegara serta membentuk sikap dan perilaku cinta tanah air bersendikan kebudayaan bangsa.

\section{Pembinaan Karakter Semangat Kebangsaan}

Pendidikan karakter telah menjadi perhatian berbagai negara dalam rangka mempersiapkan generasi yang berkualitas, bukan hanya untuk kepentingan individu warga negara, tetapi juga untuk warga masyarakat secara keseluruhan. Pendidikan karakter dapat diartikan sebagai the deliberate us of all dimensions of school life to foster optimal character development (usaha secara sengaja dari seluruh dimensi kehidupan sosial untuk membantu pembentukan karakter secara optimal). Pendidikan karakter menurut Thomas Lickona mengandung tiga unsur pokok, yaitu mengetahui kebaikan (knowing the good), mencintai kebaikan (desiring the good), dan melakukan kebaikan (doing the good). Pendidikan karakter tidak sekedar mengajarkan mana yang benar dan mana yang salah kepada anak, tetapi lebih dari itu pendidikan karakter menanamkan kebiasaan (habituation) tentang yang baik sehingga peserta didik paham, mampu merasakan, dan mau melakukan yang baik. Jadi, pendidikan karakter ini membawa misi yang sama dengan pendidikan akhlak dan pendidikan moral.

Karakter secara kebahasaan ialah sifat-sifat kejiwaan, akhlak atau budi pekerti yang membedakan seseorang dari yang lain, tabiat atau watak. Menurut Echols dan Shadily dalam (Haedar, 2013: 10) Kata karakter dipungut dari bahasa Inggris charakcter, artinya watak, sifat, peran, huruf, sedangkan characteristic artinya sifat yang khas. Menurut Dewantara dalam (Haedar: 2013: 10), karakter telah menjadi bahasa Indonesia, yang semula dari bahasa Inggris (character) dan lebih jauh lagi dari bahasa Yunani: charassein yang artinya "mengukir corak yang tetap dan tidak terhapuskan" merupakan panduan dari tabiat manusia yang bersifat tetap sehingga menjadi tanda khusus untuk membedakan orang yang satu dengan yang lain. 
Karakter artinya prilaku yang baik, yang membedakanya dari tabiat yang dimaknai dengan prilaku yang buruk. Menurut Sudewo dalam (Haedar, 2013: 10), karakter merupakan "kumpulan dari tingah laku baik dari seseorang anak manusia, tingkah laku ini merupakan perwujudan dari kesadaran menjalankan peran, fungsi, dan tugasnya mengemban amanah dan tanggung jawab", sementara tabiat sebaliknya mengindikasikan "sejumlah perangai buruk seseorang”.

Dari penjelasan di atas dapat ditarik sebuah kesimpulan bahwa karakter yang baik meliputi pengetahuan moral, perasaan moral dan tindakan moral yang secara umum saling bekerja sama untuk mendukung satu sama lainnya. Selain itu isi dari karakter yang baik adalah kebaikan. Kebaikan itu seperti kejujuran, keberanian, keadilan dan kasih sayang.

Menurut Thomas Lickona, karakter mulia (good character) meliputi pengetahuan tentang kebaikan, lalu menimbulkan komitmen (niat) terhadap kebaikan, dan akhirnya benar-benar melakukan kebaikan. Dengan kata lain, karakter mengacu kepada serangkaian pengetahuan (cognitives), sikap (attitudes), dan motivasi (motivations), serta perilaku (behaviors) dan keterampilan (skills).

Berkaitan dengan hal ini Thomas Lickona juga mengemukakan bahwa "Character education is the deliberate effort to help people understand, care about, and act upon core ethical values" (Lickona, 2012: 5).

Kutipan di atas dapat dijelaskan bahwa pendidikan karakter adalah usaha sengaja (sadar) untuk mewujudkan kebajikan, yaitu kualitas kemanusiaan yang baik secara objektif, bukan hanya baik untuk individu perseorangan, tetapi juga baik untuk masyarakat secara keseluruhan. Proses pendidikan karakter, ataupun pendidikan akhlak dan karakter bangsa sudah tentu harus dipandang sebagai usaha sadar dan terencana, bukan usaha yang sifatnya terjadi secara kebetulan. Bahkan dengan kata lain, pendidikan karakter adalah usaha yang sungguh-sungguh untuk memahami, membentuk, memupuk nilai-nilai etika, baik untuk diri sendiri maupun semua warga masyarakat atau warga negara secara keseluruhan.

Thomas Lickona dalam (Dalmeri, 2014: 272) menyebutkan tujuh unsur-unsur karakter esensial dan utama yang harus ditanamkan kepada peserta didik yang meliputi :

1. Ketulusan hati atau kejujuran (Honesty)

2. Belas kasih (Compassion)

3. Kegagahberanian (Courage)

4. Kasih sayang (Kindness)

5. Kontrol diri (Self-Control)

6. Kerja sama (Cooperation)

7. Kerja keras (Deligence or hard work)

Tujuh karakter inti (core characters) inilah, menurut Thomas Lickona, yang paling penting dan mendasar untuk dikembangkan pada peserta didik, disamping sekian banyak unsur-unsur 
karakter lainnya. Dengan demikian bahwa ketujuh karakter tersebut memang benar-benar menjadi unsur-unsur yang sangat esensial dalam mengembangkan jati diri bangsa melalui pendidikan karakter.

Untuk lebih memahami mengenai nilai-nilai karakter, dalam naskah akademik Pengembangan Pendidikan Budaya dan Karakter Bangsa, Kementerian Pendidikan dan Kebudayaan RI telah merumuskan lebih banyak nilai-nilai karakter (18 nilai) yang akan dikembangkan atau ditanamkan kepada anak-anak dan generasi muda bangsa Indonesia. Nilainilai karakter tersebut dapat dideskripsikan sebagai berikut :

1. Kreatif: Berfikir dan melakukan sesuatu untuk menghasilkan cara atau hasil baru dari sesuatu yang telah dimiliki.

2. Mandiri: Sikap dan perilaku yang tidak mudah tergantung pada orang lain dalam menyelesaikan tugas-tugas.

3. Demokratis: Cara berfikir, bersikap, dan bertindak yang menilai sama hak dan kewajiban dirinya dan orang lain.

4. Rasa Ingin Tahu: Sikap dan tindakan yang selalu berupaya untuk mengetahui lebih mendalam dan meluas dari sesuatu yang dipelajarinya, dilihat, dan didengar.

5. Semangat Kebangsaan: Cara berpikir, bertindak, dan berwawasan yang menempatkan kepentingan bangsa dan negara di atas kepentingan diri dan kelompoknya.

6. Cinta Tanah Air: Cara berpikir, bersikap, dan berbuat yang menunjukkan kesetiaan, kepedulian, dan penghargaan yang tinggi terhadap bahasa, lingkungan fisik,sosial, budaya, ekonomi, dan politik bangsa.

7. Menghargai Prestasi: Sikap dan tindakan yang mendorong dirinya untuk mengahasilkan sesuatu yang berguna bagi masyarakat, dan mengakui, serta menghormati keberhasilan orang lain.

8. Bersahabat/Komunikatif: Tindakan yang memperlihatkan rasa senang berbicara, bergaul, dan bekerja sama dengan orang lain.

9. Cinta Damai: Sikap, perkataan, dan tindakan yang menyebabkan orang lain merasa senang dan aman atas kehadiran dirinya.

10. Gemar Berbicara: Kebiasaan menyediakan waktu untuk membaca berbagai bacaan yang memberikan kebajikan bagi dirinya.

11. Peduli Llingkungan: Sikap dan tindakan yang selalu berupaya mencegah kerusakan pada lingkungan alam disekitarnya, dan mengembangkan upaya-upaya untuk memperbaiki kerusakan alam yang sudah terjadi. 
12. Peduli Sosial: Sikap dan tindakan yang selalu ingin memberi bantuan pada orang lain dan masyarakat yang membutuhkan.

13. Tanggung Jawab: Sikap dan perilaku seseorang untuk melaksanakan tugas dan kewajibannya, yang seharusnya dia lakukan, terhadap diri sendiri, masyarakat, lingkungan (alam, sosial dan budaya), negara dan Tuhan Yang Maha Esa.

Sikap dan perilaku seseorang untuk melaksanakan tugas dan kewajibannya, yang dilakukan terhadap diri sendiri, masyarakat, lingkungan (alam, sosial dan budaya), negara dan Tuhan Yang Maha Esa. Adapun dalam desain induk Pendidikan Karakter, Kementerian Pendidikan dan Kebudayaan RI juga telah menjelaskan konfigurasi karakter dalam konteks proses psikososial dan sosial-kultural dalam empat kelompok besar, yaitu:

1. Olah Hati (Spiritual and Emotional Development)

2. Olah Fikir (Intellectual Development)

3. Olah Raga dan Kinestetik (Physical and Kinesthetic Development)

4. Olah Rasa dan Karsa (Affective and Creativity Development)

Mengingat banyak nilai-nilai yang harus dikembangkan dalam pendidikan karakter, hal ini dapat diklasifikasikan dalam tiga komponen utama, yaitu:

1. Keberagamaan, terdiri dari nilai-nilai: kekhususan hubungan dengan Tuhan Yang Maha Esa, kepatuhan kepada agama, niat baik dan keikhlasan, perbuatan baik, dan pembalasan atas perbuatan baik dan buruk.

2. Kemandirian, terdiri dari nilai-nilai: harga diri, disiplin, etos kerja, rasa tanggung Jawab, keberanian dan semangat, keterbukaan, dan pengendalian diri.

3. Kesusilaan, terdiri dari nilai-nilai: cinta dan Kasih sayang, kebersamaan, kesetiakawanan, tolong-menolong, tenggang rasa, homat-menghormati, kelayakan/kepatutan, rasa malu, kejujuran, dan pernyataan terima kasih dan permintaan maaf (rasa tahu diri).

Adapun cara untuk mengajarkan nilai-nilai tersebut, Thomas Lickona (dalam Dalmeri, 2014: 277) memberikan penjelasan ada tiga komponen penting dalam membangun pendidikan karakter yaitu moral knowing (pengetahuan tentang moral), moral feeling (perasaan tentang moral) dan moral action (perbuatan bermoral). Ketiga komponen tersbeut dijadikan rujukan implementatif dalam proses dan tahapan pendidikan karakter. Selanjutnya misi atau sasaran yang harus dibidik dalam pendidikan karakter, meliputi : Pertama, kognitif, mengisi otak, mengajarinya dari tidak tahu menjadi tahu, dan pada tahap-tahap berikutnya dapat membudayakan akal pikiran, sehingga dia dapat memfungsi akalnya menjadi kecerdasan intelegensia. Kedua, afektif, yang berkenaan dengan perasaan, emosional, pembentukan sikap di dalam diri pribadi seseorang dengan terbentuknya sikap, simpati, antipati, mencintai, membenci, dan lain sebagainya. Sikap ini semua 
dapat digolongkan sebagai kecerdasan emosional. Ketiga, psikomotorik, adalah berkenaan dengan tindakan, perbuatan, perilaku, dan lain sebagainya.

Apabila dikombinasikan ketiga komponen tersebut dapat dinyatakan bahwa memiliki pengetahuan tentang sesuatu, kemudian memiliki sikap tentang hal tersebut, selanjutnya berperilaku sesuai dengan apa yang diketahuinya dan apa yang disikapinya. Karena itu, pendidikan karakter meliputi ketiga aspek tersebut, seorang peserta didik mesti mengetahui apa yang baik dan apa yang buruk. Persoalan yang muncul adalah bagaimana seseorang yang memiliki sikap terhadap baik dan buruk, dimana seseorang sampai ketingkat mencintai kebaikan dan membenci keburukan. Pada tingkat berikutnya bertindak, berperilaku sesuai dengan nilai-nilai kebaikan, sehingga menjadi akhlak dan karakter mulia.

Semangat kebangsaan atau Patriotisme adalah suatu sikap yang berani, pantang menyerah dan rela berkorban demi bangsa dan negara. Pengorbanan tersebut dapat berupa pengorbanan harta benda maupun jiwa raga. Menurut Suprapto dkk (2007: 38) menyatakan bahwa patriotisme adalah semangat cinta tanah air atau sikap seseorang yang rela mengorbankan segala-galanya untuk kejayaan dan kemakmuran tanah airnya. Patriotisme merupakan jiwa dan semangat cinta tanah air yang melengkapi eksistensi nasionalisme. Sekelompok manusia yang menghuni bumi Indonesia wajib bersatu, mencintai dengan sungguh-sungguh, dan rela berkorban membela tanah air Indonesia sebagai bangsa yang merdeka (Bakry, 2010: 144). Lebih jauh lagi, menurut Bakry (2010: 145) menyatakan bahwa patriotisme adalah bagian dari paham kebangsaan dalam nasionalisme Indonesia.

Menurut Bar-Tal (1997) menyisipkan conventional patriotism diantaranya. Staup menyatakan patriotisme sebagai sebuah keterikatan (attachmant) seseorang pada kelompoknya (suku, bangsa, partai politik dan sebagainya). Keterkaitan ini meliputi kerelaan seseorang dalam mengidentifikasikan dirinya pada suatu kelompok sosial (attachment) untuk selanjutnya menjadi loyal. Nilai patriotisme merupakan acuan atau prinsip yang mencerminkan kecintaan terhadap kelompok atau bangsa dan kesediaan untuk menjunjung nilai-nilai kemanusiaan. Patriotisme bukan hasil renungan atau pemikiran seorang atau kelompok orang tertentu. Patriotisme berangkat dari nilai-nilai yang sudah terkandung dalam sikap bangsa Indonesia terhadap tanah air. Patriotisme meliputi sikap-sikap bangga akan pencapaian bangsa, bangga akan budaya bangsa, adanya keinginan untuk memelihara ciri-ciri bangsa dan latar belakang budaya bangsa. Menurut Rashid (2004: 5) menyebutkan beberapa nilai patriotisme, yaitu: kesetiaan, keberanian, rela berkorban, serta kecintaan pada bangsa dan negara. Dalam penelitian ini, diambil dua aspek pokok dalam patriotisme, yaitu kesetiaan dan kerelaan berkorban. Makna yang terkandung dalam patriotisme (semangat kebangsaan) selalu terkait kepada tanah air, yaitu pertama adalah kecintaan 
kepada tanah air dan kedua adalah semangat membela tanah air. Kedua makna diatas akan diuraikan sebagai berikut:

\section{Cinta Kepada Tanah Air}

Cinta selalu gemerlapan dengan keindahan dalam wujud fisikanya. Keindahan selalu menjadi objek cinta, maka orang selalu mencintai keindahan. Tidak ada cinta tanpa keindahan. Jika tanah air dicintai, maka tanah air itu adalah keindahan. Keindahan itu membebaskan, menyegarkan, memulihkan dan mengilhami. Keindahan membebaskan energi besar, melepaskan wawasan terdalam, dan menghubungkan orang dengan minat tertinggi. Keindahan diibaratkan dengan zamrud di khatulistiwa, keindahan oleh rayuan pulau kelapa, keindahan oleh kekayaan budaya, kekayaan alam yang melimpah, semuanya ibarat hamparan mosaik tiada banding. Keindahan tanah air telah diaktualkan dalam semboyan Bhina Ika Tunngal Ika, artinya beda itu, bersatu itu, dituliskan: "Bhineka Tunggal Ika".

Semakin ingin memperindah dan memperkaya mosaik tanah air, semakin dibutuhkan karya unggul dan cemerlang dari setiap warga negara. Karya unggul dan cemerlang dapat dihasilkan dengan suatu kekuatan kemampuan. Oleh karena itu, kekuatan kecintaan kepada tanah air sangat diharapkan dimiliki oleh setiap warga negara yang ingin disebut sebagai patriot.

2. Semangat Membela Tanah Air

Semangat yang dalam kamus merupakan salah satu pengertian dari kata spirit (dalam Bahasa Inggris) tidak cukup hanya terkait kepada kehidupan keagamaan. Pembelaan tanah air dalam berbagai bentuk pekerjaan yang mulia atau dibenarkan oleh agama dan pandangan umum (common cence) tidak terlepas dari kebutuhan semangat untuk memperoleh kepuasan. Semakin terikat setiap warga negara kepada kepekerjaannya, semakin kuat semangatnya dan semakin besar kepuasannya yang diperolehnya. Semakin terikat seseorang kepada pekerjaan semakin banyak ia memahami dan mendalami pekerjaan itu. Pada gilirannya, semangatnya semakin kuat dari waktu kewaktu, artinya semangatnya tidak pernah padam.

Semangat dapat menular dan ditularkan kepada orang lain, atau orang lain akan ikut bersemangat dalam pekerjaan mereka. Bukan bearti bahwa semangat itu tidak pernah terkendala atau menghadapi tantangan. Tidak tetutup kemungkinan semangat itu pudar atau sirna pada setiap orang karena suatu musibah, tetapi semangat yang sejak dari awal sudah menetap berakar pada jiwa orang itu akan bangkit dan menantang lagi. Kondisi demikian ini menjadikan seseorang memiliki kedayatahanan (adversity) atau keuletan.

Inti semangat adalah keterikatan, jatuh dan bangun tetap dalam keterikatan. Semangat membela tanah air adalah keterikatan kepada kemajuan dan keutuhan bangsa dan negara adalah keterikatan sesama warga negara, antara warga negara dan seluruh nusantara serta seluruh isinya 
atau seluruh alamnya yang berada didarat, laut dan udara. Itulah makna semangat membela tanah air, suatu keterikatan dan keutuhan yang tertinggi, tidak dapat ditawar lagi.

\section{SIMPULAN}

Secara umum pembinaan karakter semangat kebangsaan siswa melalui ekstrakurikuler paskibra di SMAN se-kota Pontianak telah memberikan pengaruh terhadap pembentukan karakter dan sikap semangat kebangsaan siswa. Dengan demikian secara khusus dapat disimpulkan sebagai berikut:

1. Perencanaan program Perencanaan program ekstrakurikuler paskibra dirancang oleh berbagai pihak yakni pembimbing kesiswaan, pelatih sekaligus pembina paskibra dan juga anggotaanggota paskibra yakni siswa-siswi yang mengikuti kegiatan ekstrakurikuler paskibra. Dalam struktur organisasi ekstrakurikuler paskibra ada lima pihak yang berperan. Pertama pihak yang berperan adalah Kepala Sekolah, pembimbing kesiswaan, pembina paskibra, pelatih paskibra, dan komandan paskibra. Program yang telah dirancang dalam pelaksanaan ekstrakurikuler paskibra antara lain kegiatan rutin, Kegiatan rutin ekstrakurikuler paskibra dilaksanakan pada hari Sabtu pada pukul 13.00 WIB sampai selesai. Pelaksanaan kegiatan rutin ini diharapkan dapat menanamkan serta menumbuhkan sikap semangat kebangsaan siswa. Kegiatan yang dilakukan oleh Paskibra adalah (1) Kegiatan rutin berisi pemberian materi-materi kepaskibraan yang meliputi kegiatan latihan, latihan bendera merah putih, lagu kebangsaan, dan materi tentang mental. Kemudian untuk materi lapangan yakni pelatihan baris berbaris, fisik, upacara, dan outbond. (2) Upacara hari senin, (3) Upacara hari-hari besar nasional, (4) Perlombaan paskibra, (5) Peringatan HUT RI, (6) pengadaan seragam, (7) Latihan gabungan paskibra, dan (8) Pelaksanaan formasi.

2. Sesuai dengan rancangan program yang telah disetujui oleh Kepala Sekolah, pelaksanaan program paskibra mengacu pada program yang telah dibuat, antara lain (1) Melaksanakan kegiatan rutin yaitu latihan rutin setiap hari Sabtu, (2) Upacara Hari Senin merupakan kegiatan rutin yang dilaksanakan setiap Hari Senin yang wajib diikuti oleh staf-staf sekolah beserta seluruh siswa, (3) Upacara hari-hari besar Nasional, kegiatan ini dilaksanakan di dalam lingkungan sekolah ataupun di luar lingkungan sekolah, (4) Perlombaan paskibra, beberapa SMAN di kota Pontianak mendapatkan prestasi yang membanggakan, kerjasama antara pihak sekolah, pembimbing, pelatih, dan juga siswa-siswi sangat kompak dan solid, (5) Pelaksnaan HUT RI, sama halnya dengan upacara hari-hari besar nasional yang menjadi petugas uapacara adalah siswa-siswi yang mengikuti ekstrakurikuler paskibra di sekolah, (6) Pengadaan seragam, kegiatan ini rutin dilakukan setiap tahun sekali, pengadaan seragam ini dilakukan dengan tujuan kekompakan dan keserasian siswa , (7) Latihan gabungan paskibra yang 
merupakan program yang dirancang oleh pihak sekolah, (8) Pelaksanaan formasi, anggota pasukan pengibar bendera dituntut untuk mampu berkreasi membuat formasi dengan bimbingan pelatih. Setiap pelaksanaan kegiatan paskibra diatas akan membawa pengaruh terhadap siswa yaitu membangun rasa persatuan dan kesatuan, keakraban serta kekeluargaan antar siswa, disiplin, bertanggung jawab, menggalang sikap kepemimpinan, serta membina kekompakan dan kerja sama.

3. Pelaksanaan kegiatan ekstrakurikuler Paskibra menemui beberapa kendala, kendala-kendala tersebut berasal dari faktor internal, eksternal, baik dari lingkungan sekolah maupun dari luar lingkungan sekolah.kendala-kendala tersebut diantaranya adalah kurangnya minat dan motivasi siswa untuk mengikuti kegiatan ekstrakurikuler Paskibra, jadwal kegiatan ekstrakurikuler yang masih sering berbenturan dengan kegiatan-kegiatan siswa yang lain seperti kegiatan ekstrakurikuler selain paskibra, tugas kelompok, les, masalah dengan kegiatan olimpiade juga merupakan kendala yang perlu diatasi. Pemberian materi yang disampaikan oleh pelatih, siswa cenderung bosan dengan materi paskibra dan materi lapangan, hal tersebut menyebabkan siswa tidak dapat menyerap materi dengan baik. Kemudian kendala dari pihak orangtua cenderung tidak mengiginkan anak-anaknya untuk mengikuti kegiatan paskibra yang hanya membuat anaknnya tidak dapat konsentrasi dan tidak dapat menerima pelajaran dengan baik di sekolah.

4. Pembina sekaligus pelatih Paskibra dan juga pihak sekolah harus dapat membangun minat dan memotivasi siswa agar lebih semangat lagi dalam mengikuti kegiatan ekstrakurikuler paskibra. Jadwal kegiatan Paskibra yang berbenturan dengan kegiatan ekstrakurikuler yang lain pihak sekolah berupaya untuk mengatur jadwal kegiatan Paskibra agar tidak bersamaan dengan kegiatan ekstrakurikuler yang lain. Kemudian pihak sekolah harus berkolaborasi dengan pembimbing kesiswaan dan pelatih untuk melakukan musyawarah kepada orangtua siswa agar tidak khawatir dengan prestasi anaknya apabila aktif menguiti kegiatan paskibra. pihak orangtua diberi pengertian bahwa kegiatan paskibra tersebut memiliki banyak hal yang positif dan bermanfaat bagi siswa.

\section{DAFTAR PUSTAKA}

Asep Herry H, dkk. 2011. Pengembangan Kurikulum dan Pembelajaran. Jakarta: Penerbit UT.

Arif S. Sadiman, dkk . 2012. Media Pendidikan: Pengertian, Pengembangan, dan Pemanfaatannya. Jakarta: PT. Raja Grafindo Persada.

Bakry Noor Ms. 2010. Pendidikan Pancasila. Yogyakarta: Pustaka Belajar

Bar-Tal, D., \& Staub, E. (Eds). 1997. Patriotism in the life of individuals and nations. Chicago: Nelson-Hall. 
Dalmeri. 2014. Pendidikan Untuk Pengembangan Karakter: Telaah terhadap Gagasan Thomas Lickona dalam Educating for Character. Jurnal Al-Ulu. Vol. 14(1), 269-288

Daryanto \& Suryatri. 2013. Implementasi Pendidikan Karakter di Sekolah. Bandung: Gava Media. Departeman pendidikan nasional. 1997. Kamus Besar Bahasa Indonesia. Jakarta: Balai Pustaka.

Gunawan, Heri. 2012. Pendidikan Karakter, Konsep dan Implementasi. Bandung: Alfabeta.

Haedar Nashir. 2013. Pendidikan Karakter Berbasis Agama dan Budaya. Yogyakarta: Multi Presindo

Ilahi, Mohammad Takdir. 2012. Pembelajaran Discovery Strategy dan Mental Vocational Skill. Yogyakarta: Diva Press.

Komalasari, 2009. Pendidikan Kewarganegaraan Untuk SD/MI Kelas 6. Jakarta: Pusat Perbukuan Depdiknas

Lickona, Thomas. 2012. Character Matters. Jakarta: PT. Bumi Aksara

Manan dan Lan. 2011. Nasionalisme dan Ketahanan Budaya di Indonesia: Sbuah Tantangan. Jakarta: LIPI \& Obor Indonesia

Rashid, Abd. Rahim. 2004. Patriotisme: Agenda Pembinaan Bangsa. Kuala Lumpur: Utusan Publication.

Sugiyono. (2010). Metode Penelitian Pendidikan (Pendekatan Kuantitatif, Kualitatif dan $R$ \& D). Alfabeta: Bandung.

Suprapto dkk. 2007. Pendidikan Kewarganegaraan Kelas X SMA/MA 1. Jakarta: PT. Bumi Aksara.

Tilaar. A.R. 2007. Mengindonesia: Etnisitas dan Identitas Bangsa Indonesia. Jakarta: Rineka Cipta

Zainal Aqib \& Sujak. 2011. Panduan dan Aplikasi Pendidikan Karakter. Jakarta: Gaung Persada Press 